\title{
Environmental controls of lucerne (Medicago sativa L.) growth across a climatic and edaphic gradient
}

Druille, M., Deregibus V. and Garbulsky, M. F.

\begin{abstract}
SUMMARY
Lucerne is one of the most valuable forage species because of its high productivity and nutritional traits. However, the knowledge of spatio-temporal variability and environmental controls of its growth generated from the simultaneous study of several sites and throughout several years is extremely scarce. Five-year biomass data were analyzed from four rain fed sites located across a climatic and edaphic gradient in Argentina. The aims proposed were to characterize annual and seasonal lucerne growth, to analyze environmental controls of spatial and temporal growth, and to compare water use efficiency (WUE) among sites. Annual growth differed significantly among sites, ranging between 7,514 and $14,262 \mathrm{~kg} \mathrm{DM} / \mathrm{ha}$. This range at the spatial scale was mainly explained by variations in annual rainfall and WUE among sites. Seasonal growth depended on incident radiation and actual evapotranspiration. Interannual variability of lucerne growth was explained by precipitation occurred during the growing season in the driest sites, on sandy soils with less water retention capacity. Knowing the sources of variability of lucerne growth, would allow developing more efficient livestock management due to less uncertainty on the forage production dynamics.
\end{abstract}

Key words: soil properties, water use efficiency, forage production, climate.

Druille, M., Deregibus V. y Garbulsky, M. F. , 2017. Controles ambientales del crecimiento de alfalfa (Medicago sativa L.) a lo largo de un gradiente climático y edáfico. Agriscientia 34 (II): 13-23

\section{RESUMEN}

Laalfalfaesuna de las especiesforrajeras más valoradas por sualta productividad y características nutritivas. Sin embargo, el conocimiento de la variabilidad espacio-temporal y los controles ambientales del crecimiento generado a partir del estudio simultáneo de varios sitios y años es extremadamente escaso. En este trabajo se analizaron cinco años de datos de biomasa de cuatro sitios de secano ubicados a lo largo de un gradiente climático y edáfico en Argentina. Los objetivos propuestos fueron: caracterizar el crecimiento anual y estacional de la alfalfa, analizar los controles ambientales del crecimiento a escala espacial y temporal y comparar la eficiencia en el uso del agua (EUA) entre

Fecha de recepción: 21/12/2016; fecha de aceptación: 29/11/2016. 
sitios. El crecimiento anual difirió espacialmente, oscilando entre 7.514 y 14.262 $\mathrm{kg} \mathrm{MS} / \mathrm{ha}$. Esta variabilidad fue principalmente explicada por variaciones en las precipitaciones anuales y la EUA. El crecimiento estacional dependió de la radiación incidente y la evapotranspiración real. La variabilidad interanual del crecimiento fue explicada por la precipitación ocurrida durante la estación de crecimiento en los sitios secos, con suelos arenosos de baja capacidad de retención hídrica. Conocer las fuentes de variación en el crecimiento de alfalfa permitirá el desarrollo de prácticas de manejo ganadero más eficientes debido a la menor incertidumbre en la dinámica de producción forrajera.

Palabras clave: propiedades edáficas, eficiencia en el uso del agua, producción de forraje, clima.

M. Druille y A. V. Deregibus: Departamento de Producción Animal, Facultad de Agronomía, Universidad de Buenos Aires. Av. San Martín 4453, C1417DSE, Buenos Aires, Argentina. M. F. Garbulsky: Departamento de Producción Animal, Facultad de Agronomía, Universidad de Buenos Aires. IFEVA-CONICET. Av. San Martín 4453, C1417DSE, Buenos Aires, Argentina. Correspondence to: druille@agro.uba.ar

\section{INTRODUCTION}

Plant growth is a key aspect of ecosystem functioning because of its cascade effects on herbivore production, nutrient cycling and ecosystem carbon exchange (McNaughton, Oesterheld, Frank and Williams, 1989; Jackson et al., 2000). Environmental controls of plant growth vary with the spatio-temporal scale of analysis. In herbaceous vegetation ecosystems, average annual rainfall (Di Bella et al., 2009; Garbulsky et al., 2010; Sala, Gherardi, Reichmann, Jobbagy and Peters, 2012) and actual evapotranspiration (Lo Seen Chong, Mougin and Gastellu-Etchegorry, 1993; Garbulsky et al., 2010) determines the regional variability of annual production. For a given site, interannual precipitation variability also regulates changes in growth rate, even though a considerable amount of variability remains unexplained (Knapp and Smith, 2001; Fabricante, Oesterheld and Paruelo, 2009; Sala et al., 2012). Regarding seasonal variations in plant growth, it was found that this variation was best determined by rainfall in some cases (Fay, Carlisle, Knapp, Blair and Collins, 2003; Murphy, 1970), or monthly temperatures in others (Bissio, 1996; Primavesi, 1999).

Lucerne (Medicago sativa L.) is the most widely cultivated forage legume, and is an important component of forage production for livestock industries worldwide. The widespread use of this species is due to its high production and forage quality, its positive effects on soil fertility and its adaptation to a wide range of climate and soil conditions (Dovrat, 1993; Campiglia, Caporali, Barberi and
Mancinelli, 1999; Huyghe, 2003). Moreover, it has been demonstrated that the use of forage legumes in agricultural rotations allows important increases in soil carbon sequestration and reductions in the $\mathrm{C}$ footprint (Gattinger et al., 2012; Ma, Liang, Biswas, Morrison and McLaughlin, 2012; Teague et al., 2016). As far as we know, very few studies have simultaneously analyzed in time and space the environmental controls of lucerne growth in rainfed conditions (Bowman, Smith and Brockwell, 2004; Hakl, Fuksa, Konecná, Pacek and Tlustoš, 2014). Thus, there is a lack of information on the factors explaining its growth variability both at temporal and spatial scale.

Seasonal variability of lucerne production was positively associated with intercepted radiation (Collino, Dardanelli, De Luca and Racca, 2005; Brown, Moot and Teixeira, 2006; Mattera, Romero, Cuatrín, Cornaglia and Grimoldi, 2013). Positive relationships between lucerne growth and evapotranspiration have been reported (Saeed and ElNadi, 1997; Singh et al., 2007), although these relationships are generally site and cultivar specific. The variability of these relationships could be explained by changes in the water use efficiency (WUE) among sites. At canopy level, WUE is defined as the ratio of aboveground biomass to water use or evapotranspiration (ET), and it has been demonstrated that this efficiency varies according to soil properties and climatic factors (Smeal et al., 1992). Therefore, there is a need to obtain improved estimations of WUE for local site conditions and over different seasons so that the dry matter production may be more accurately predicted 
(Pembleton, Rawnsley and Donaghy, 2011).

The aims of this study were a) to characterize annual and seasonal lucerne growth b) to analyze the environmental controls that determine spatial and temporal growth variability; and c) to compare annual and seasonal WUE among sites. Temporal growth variability and WUE were analyzed seasonally and annually at four sites across a climatic and edaphic gradient in the Pampa region of Argentina, the second worldwide largest cultivator of lucerne in terms of cropped area (Basigalup and Ustarroz, 2007). This gradient spans $353 \mathrm{~mm}$ in annual precipitation (from 753 to $1106 \mathrm{~mm} / \mathrm{yr}$ ), $4.5^{\circ} \mathrm{C}$ in mean annual temperature (from 14.9 to $19.4^{\circ} \mathrm{C}$ ), and soils ranging from sandy to silt loam. This investigation was focused on precipitation, temperature, actual evapotranspiration and incident radiation as main controls of lucerne growth.

\section{MATERIAL AND METHODS}

\section{Study sites and trial characterization}

Growth data gathered by biomass harvest networks were analyzed at four sites located within the Pampa region in Argentina. Soils and climatic characteristics are detailed in Tables 1 and 2 . Sites 1-3 (Rafaela, Mercedes and Coronel Suárez, respectively) are part of the network for evaluation of genetic material managed by the Cámara de Semilleristas de la Bolsa de Cereales (Pastura
Test, 1991, 1995, 1997, 1998, 1999, 2000, 2001, 2003, 2004, 2005), and Site 4 (Anguil) is part of the evaluation network managed by the Instituto Nacional de Tecnología Agropecuaria (Spada et al., 2015). These networks consist of 3 to 4 years of crop trials which record accumulated biomass between successive harvests of commercial cultivars. Trials consist of randomized blocks with four replicates of each cultivar. Plots of $5 \mathrm{~m} \times 1.4 \mathrm{~m}$ or $5 \mathrm{~m} \times 1 \mathrm{~m}$ are sown in autumn with 12 or $20 \mathrm{~kg} /$ ha of seeds (in the case of CSBC or INTA network, respectively). Biomass is simultaneously harvested from all cultivars when most of the plants reach the $10 \%$ flowering stage, or when the shoots from the crown measure approximately $5 \mathrm{~cm}$. Fresh weight of each plot is recorded, and a sample is taken to determine the percentage of dry matter. A similar harvesting protocol (i.e. criteria to define harvest date) is used at the four sites, allowing a temporal and spatial comparison of the data.

\section{Annual and seasonal lucerne biomass produc- tion}

At each site, data from lucerne trials sowed in five different years were analyzed. The biomass accumulated in the second year after sowing was used for each of these trials (Table 1). Data from two cultivars were averaged (Monarca SP INTA and CUF 101) characterized by being widely used both in time and space in livestock systems. Both

Table 1: Geographical coordinates, climatic and edaphic characteristics of the studied sites. Values of climatic variables represent the average of all the years considered in this analysis \pm E.E.

\begin{tabular}{|c|c|c|c|c|}
\hline & Site 1 & Site 2 & Site 3 & Site 4 \\
\hline Latitude & $31^{\circ} 11^{\prime} \mathrm{S}$ & $34^{\circ} 36^{\prime} \mathrm{S}$ & $37^{\circ} 11^{\prime} \mathrm{S}$ & $36^{\circ} 30^{\prime} \mathrm{S}$ \\
\hline Longitude & $61^{\circ} 30^{\prime} \mathrm{W}$ & $59^{\circ} 04^{\prime} \mathrm{W}$ & $62^{\circ} 08^{\prime} \mathrm{W}$ & $63^{\circ} 50^{\prime} \mathrm{W}$ \\
\hline Annual precipitation ( $\mathrm{mm} / \mathrm{yr}$ ) & $1106 \pm 50$ & $1023 \pm 127$ & $764 \pm 59$ & $753 \pm 71$ \\
\hline Mean temperature $\left({ }^{\circ} \mathrm{C}\right)$ & $19.4 \pm 0.1$ & $17.8 \pm 0.4$ & $14.9 \pm 0.5$ & $17.5 \pm 0.3$ \\
\hline Incident radiation $\left(\mathrm{MJ} / \mathrm{m}^{2} . \mathrm{d}\right)$ & $19.0 \pm 0.5$ & $19.7 \pm 0.6$ & $18.8 \pm 0.8$ & $20.5 \pm 0.5$ \\
\hline Annual ETP (mm/yr) & $1334 \pm 26$ & $1361 \pm 22$ & $1184 \pm 20$ & $1250 \pm 20$ \\
\hline Annual ETA (mm/yr) & $835 \pm 73$ & $909 \pm 123$ & $736 \pm 67$ & $693 \pm 42$ \\
\hline Soil type & Typicargiudoll & Typicargiudoll & Typichapludoll & Entichapludoll \\
\hline Texture & Silt loam & Silt loam & Clay loam & Sandy loam \\
\hline Soil field capacity (mm) & 350 & 325 & 135 & 114 \\
\hline $\mathrm{pH}$ & 6.2 & 5.7 & 6.7 & 6.5 \\
\hline Soil Organic Matter (\%) & 3.5 & 3 & 4.5 & 2.3 \\
\hline \multirow[t]{3}{*}{ Phosphorus (ppm) } & 60 & 9 & 12 & 18 \\
\hline & 1997/1998 & 1998/1999 & $1991 / 1992$ & 1997/1998 \\
\hline & 1998/1999 & 1999/2000 & 1995/1996 & 1999/2000 \\
\hline \multirow[t]{3}{*}{ Years evaluated } & $1999 / 2000$ & 2000/2001 & 1998/1999 & 2001/2002 \\
\hline & 2000/2001 & 2001/2002 & 1999/2000 & 2003/2004 \\
\hline & 2001/2002 & 2004/2005 & $2001 / 2002$ & 2005/2006 \\
\hline
\end{tabular}

ETP: Potential evapotranspiration; ETA: Actual evapotranspiration. 
Table 2: Climatic characterization of each site at seasonal scale. Values are mean \pm E.E. of the five years evaluated.

\begin{tabular}{|c|c|c|c|c|c|}
\hline & & Site 1 & Site 2 & Site 3 & Site 4 \\
\hline \multirow{4}{*}{$\begin{array}{l}\text { Precipitation } \\
\text { (mm/season) }\end{array}$} & Autumn & $238 \pm 64$ & $212 \pm 76$ & $174 \pm 31$ & $145 \pm 16$ \\
\hline & Winter & $147 \pm 6$ & $177 \pm 31$ & $171 \pm 27$ & $207 \pm 48$ \\
\hline & Spring & $282 \pm 63$ & $326 \pm 99$ & $163 \pm 22$ & $167 \pm 43$ \\
\hline & Summer & $410 \pm 88$ & $308 \pm 46$ & $255 \pm 43$ & $234 \pm 45$ \\
\hline \multirow{4}{*}{$\begin{array}{l}\text { Mean temperature } \\
\qquad\left({ }^{\circ} \mathrm{C}\right)\end{array}$} & Autumn & $15.7 \pm 0.7$ & $16.7 \pm 1.6$ & $14.7 \pm 0.4$ & $15.8 \pm 1.3$ \\
\hline & Winter & $14.2 \pm 0.2$ & $12.7 \pm 0.9$ & $9.5 \pm 0.4$ & $15.0 \pm 1.8$ \\
\hline & Spring & $20.6 \pm 0.6$ & $18.4 \pm 1.9$ & $16.1 \pm 0.6$ & $20.9 \pm 1.4$ \\
\hline & Summer & $23.7 \pm 0.2$ & $22.1 \pm 0.3$ & $20.2 \pm 0.1$ & $15.5 \pm 1.6$ \\
\hline \multirow{4}{*}{$\begin{array}{l}\text { Incident radiation } \\
\qquad\left(\mathrm{MJ} / \mathrm{m}^{2} \cdot \mathrm{d}\right)\end{array}$} & Autumn & $6.0 \pm 0.2$ & $5.9 \pm 0.3$ & $5.8 \pm 0.2$ & $5.9 \pm 0.7$ \\
\hline & Winter & $5.0 \pm 0.3$ & $4.4 \pm 0.2$ & $5.1 \pm 0.4$ & $5.3 \pm 0.3$ \\
\hline & Spring & $9.5 \pm 0.2$ & $8.6 \pm 0.8$ & $9.9 \pm 0.4$ & $10.6 \pm 0.4$ \\
\hline & Summer & $9.8 \pm 0.3$ & $9.9 \pm 0.5$ & $10.0 \pm 0.2$ & $9.6 \pm 0.2$ \\
\hline \multirow{4}{*}{$\begin{array}{l}\text { Actual evapotranspiration } \\
\qquad(\mathrm{mm} / \mathrm{d})\end{array}$} & Autumn & $1.35 \pm 0.10$ & $1.78 \pm 0.16$ & $2.2 \pm 0.17$ & $1.43 \pm 0.33$ \\
\hline & Winter & $1.04 \pm 0.05$ & $1.33 \pm 0.11$ & $0.93 \pm 0.11$ & $0.82 \pm 0.05$ \\
\hline & Spring & $2.67 \pm 0.56$ & $2.58 \pm 0.45$ & $2.10 \pm 0.23$ & $2.27 \pm 0.20$ \\
\hline & Summer & $3.29 \pm 0.64$ & $2.90 \pm 0.39$ & $2.87 \pm 0.32$ & $2.80 \pm 0.17$ \\
\hline
\end{tabular}

cultivars have no winter growing dormancy (dormancy rating grades 8 and 9 , respectively). Annual biomass production corresponds to the sum of the biomass in each harvest within a second year of growing. Seasonal growth was estimated by two calculation steps. Firstly, the growth rate for the period between two harvests was estimated by the ratio of the accumulated biomass and the days elapsed between them. The second step was to perform a weighted average of lucerne growth rate for all the harvests in the same season.

\section{Edaphic and environmental variables}

Precipitation and temperature data were obtained from weather stations located at each site. Seasonal precipitation and temperature were calculated adding and averaging daily precipitation and temperature of each of the four seasons, respectively. Growing season (GS) precipitation was calculated adding only spring and summer precipitation. Incident radiation $\left(R_{S}\right)$ in $\mathrm{MJ} / \mathrm{m}^{2}$. day, was calculated as (Samani, 2000):

$$
R s=\operatorname{RoKT}(T M-T m)^{0.5}
$$

where $R_{O}$ is the global extraterrestrial radiation, $T_{M}$ the maximum and $T_{m}$ the minimum daily temperatures. KT is an empirical coefficient with a value of 0.162 for sites located in interior regions like the sites studied (Hargreaves, 1994). $R_{O}$ was extracted from tabulated values depending on the latitude and moment of the year (Allen et al., 1998). Daily $R_{S}$ estimations for all sites obtained with this methodology were validated using data obtained from NASA Prediction of Worldwide Energy Resource method (http://power.larc.nasa.gov/). These methodologies were highly consistent with each other (Linear regression: $R^{2}=0.71 ; p<0.001$; the slope did not differed significantly to the 1: 1 line slope; $p=0.89$ ).

Daily actual evapotranspiration (ETA) was estimated from potential evapotranspiration (ETP) and relative evapotranspiration, which depends on plant available water (PAW) and atmospheric demand (Figure 1). Daily ETA was assumed to be equal to ETP when plant available soil water (PAW) was higher than a critical threshold, and to decline linearly with PAW between 0 and that threshold. PAW threshold depends on the plant species, being in the case of lucerne of 0.39 and 0.46 for periods of lowest and highest atmospheric demand, respectively (Sadras and Milroy, 1996). Daily ETP (mm) was estimated as (Hargreaves and Samani, 1985):

$\mathrm{ETP}=0.0135$ Rs (Mean daily temperature + 17.8) (2)

Hargreaves equation was used because it is the most appropriate under conditions of data scarcity (Xu and Singh, 2001; Droogers and Allen, 2002). PAW used in the water balance was calculated as (Ritchie, 1981):

$$
P A W=\underline{\varnothing-P W P}
$$

where the volumetric water content in soil $(\varnothing)$ resulted from the balance between the evapotranspired water and the water content of the previous 


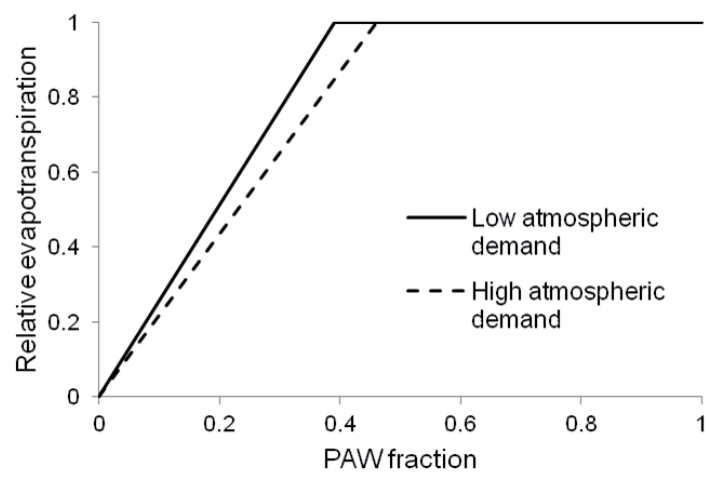

Figure 1: Relationship between relative evapotranspiration and plant available water (PAW) fraction. PAW thresholds were 0.39 and 0.46 for periods of lowest and highest atmospheric demand, respectively (Sadras and Milroy, 1996). Adapted from Sadras et al.(1993).

day and precipitation occurred the current day. Soil field capacity (FC) and permanent wilting point (PWP) were estimated taking into account the soil texture of each site and lucerne rooting depth (Saxton et al., 1986). Rooting depth varied among sites depending on physical limitations for root growth characteristic of each soil, such as presence of caliche layers or textural B horizon (Moscatelli and Puentes, 1998). Monthly ETA was calculated by averaging the daily ETA of all the days of the month. Seasonal ETA was estimated by averaging the monthly ETA of the months of each season, and growing-season (GS) ETA by averaging only spring and summer ETA. Annual ETA was calculated adding daily ETA of every day of the year.

\section{Water use efficiency (WUE)}

Annual and seasonal WUE (kg DM/ha.mm) were calculated as:

$$
\text { WUE }=\frac{\text { Biomass }}{\text { ETA }} \text { (4) }
$$

where biomass (kg DM/ha) refers to aboveground biomass and ETA $(\mathrm{mm})$ refers to actual evapotranspiration.

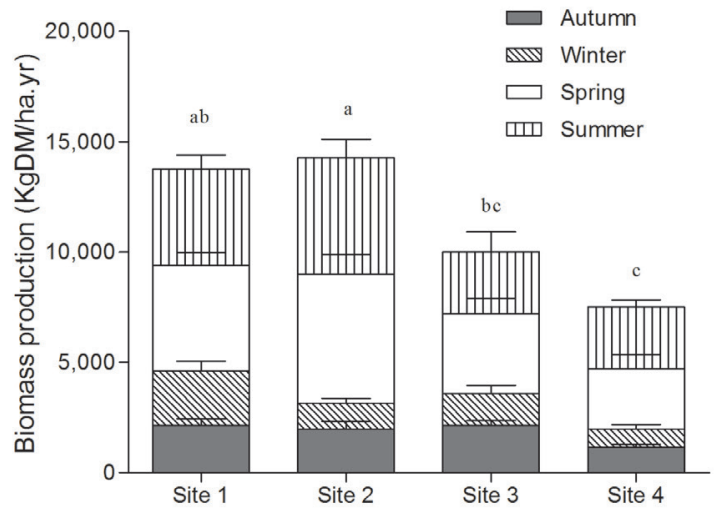

Figure 2: Lucerne biomass production at the annual and seasonal scales. The total values of the bars are means of five years in each experimental site. Error bars indicate SE for each season. Different letters above bars indicate that annual biomass values significantly differ among sites according to Tukey's test $(P \leq 0.05)$.

\section{Statistical analysis}

One-way analysis of variance (ANOVA) was used to compare lucerne growth, and two-way ANOVA to compare WUE between seasons and sites. In the cases when ANOVA identified significant effects (i.e. $P<0.05$ ), treatment means were compared using Tukey test. The relationship between lucerne growth and climate variables was analyzed using the Pearson correlation coefficient $(r)$ and simple and multiple lineal regression analysis. All analyses were performed using InfoStat software (Di Rienzo, Casanoves, Balzarini, Gonzalez, Tablada y Robledo, 2011).

\section{RESULTS AND DISCUSSION}

Annual biomass production differed among sites, ranging between 7,514 and 14,262 kg DM/ ha.yr (Figure 2), being annual precipitation the variable accounting for the great part of this spatial variability (Table 3). Regression analysis showed a positive and linear relationship between both variables (Figure 2). These results are consistent with those reported from different environments in Australia by Bowman et al. (2004), who found that annual rainfall itself was an indicator of lucerne

Table 3: Degree of correlation (Pearson coefficient) between lucerne annual biomass production and climate variables at regional scale.

\begin{tabular}{|c|c|c|c|c|c|c|}
\hline & $\begin{array}{c}\text { Annual } \\
\text { precipitation } \\
(\mathrm{mm} / \mathrm{yr})\end{array}$ & $\begin{array}{c}\text { GS precipitation } \\
\text { (mm/GS) }\end{array}$ & $\begin{array}{c}\text { Annual } \\
\text { ETA } \\
(\mathrm{mm} / \mathrm{yr})\end{array}$ & $\begin{array}{c}\text { GS ETA } \\
(\mathrm{mm} / \mathrm{GS})\end{array}$ & $\begin{array}{l}\text { Incident } \\
\text { radiation } \\
\left(\mathrm{MJ} / \mathrm{m}^{2} . \mathrm{d}\right)\end{array}$ & $\begin{array}{c}\text { Mean } \\
\text { temperature } \\
\left({ }^{\circ} \mathrm{C}\right)\end{array}$ \\
\hline$r$ & 0.71 & 0.55 & 0.52 & 0.39 & 0.00 & 0.43 \\
\hline$P$-value & $<0.001$ & 0.01 & 0.02 & 0.09 & 0.99 & 0.06 \\
\hline
\end{tabular}

GS: Growing season (spring and summer); ETA: Actual evapotranspiration. 
productivity irrespective of its distribution, evapotranspiration or soil temperature. However, results from this study indicate a twofold slope in the relation between annual growth and precipitation compared to that found in Australian environments. These differences might be explained by the drier sites (annual rainfall ranging from 160 to $680 \mathrm{~mm} / \mathrm{y}$ ) studied by Bowman et al. (2004), compared to the sites analyzed in this study, located in wetter environments (570 to $1,400 \mathrm{~mm} / \mathrm{yr}$ ) within the Pampa region. Soils in humid environments are normally characterized by having higher fertility and biological activity than dry environments soils (Boix-Fayos et al., 1998; McKenzie and Ryan, 1999; Raich and Tufekciogul, 2000), and this would explain the higher biomass produced per unit of evapotranspired water. Moreover, in the study of Bowman et al. (2004), annual precipitation explained a greater proportion of biomass variability $(r=0.84)$, probably because plant growth dependency on precipitation is higher in drier than in wetter environments. At drier sites in the Pampa region, inter-annual growth variability was accounted for by the growing season precipitation (Site 3 and 4 ) and by growing season ETA (Site 3) (Table 4). This may be related not only to less water availability in these environments, but also to lower soil water-holding capacity (Table 1). Lucerne growth at these sites hence would depend on growing season precipitation, unlike wetter sites that may use precipitation of previous periods. This result agrees with those previously reported in grassland systems (Fetcher and Trlica, 1980; Robinson et al., 2012). At Site 2, incident radiation and mean temperature have a marginal impact on this variability (Table 4). Temperature could impact alfalfa growth directly, or indirectly by influencing mineralization rates (Jarvis, Stockdale, Shepherd and Powlson, 1996) and therefore nutrient availability.

Although Sites 1 and 2 did not differ in terms of annual production, they differed in terms of their seasonal growth distribution (Figure 2). Winter growth rate at Site 1 was $60 \%$ higher than at Site 2, but spring and summer growth rates were lower at Site 1 (Table 5). Site 4 presented the highest seasonality ( $70 \%$ of annual growth was concentrated in spring and summer). All responses explained above are evidenced by the significant site $x$ season interaction found $(P=0.0131)$. Seasonal growth was largely explained by seasonal ETA and inci-

Table 4: Degree of correlation (Pearson coefficient) between lucerne annual biomass production and climate variables for each site at temporal scale.

\begin{tabular}{ccccc}
\hline & Site 1 & Site 2 & Site 3 & Site 4 \\
\hline Annual precipitation $(\mathrm{mm} / \mathrm{yr})$ & 0.46 & 0.40 & 0.70 & 0.72 \\
Annual ETA $(\mathrm{mm} / \mathrm{yr})$ & -0.67 & 0.46 & 0.63 & 0.35 \\
Incident radiation $\left(\mathrm{MJ} / \mathrm{m}^{2} . \mathrm{d}\right)$ & 0.51 & $\mathbf{0 . 8 4}^{*}$ & 0.01 & -0.51 \\
Mean Temperature $\left({ }^{\circ} \mathrm{C}\right)$ & 0.07 & $\mathbf{0 . 8 3}^{*}$ & 0.31 & -0.41 \\
GS precipitation $(\mathrm{mm} / \mathrm{GS})$ & 0.05 & -0.19 & $\mathbf{0 . 9 6}^{* *}$ & $\mathbf{0 . 9 1}^{* *}$ \\
GS ETA $(\mathrm{mm} / \mathrm{GS})$ & -0.68 & 0.32 & $\mathbf{0 . 9 4}^{* *}$ & 0.86 \\
\hline
\end{tabular}

GS: Growing season (spring and summer); ETA: Actual evapotranspiration. Bold denotes significant effects at ${ }^{*} P<0.1 ;{ }^{* *} P<0.05$.

Table 5: Seasonal lucerne growth rate of each site (KgDM/ha.d).

\begin{tabular}{ccccc}
\hline Site & Autumn & Winter & Spring & Summer \\
\hline 1 & $24.5 \pm 4.2$ & $23.9 \pm 3.5$ & $56.1 \pm 6.2$ & $52.1 \pm 6.5$ \\
2 & $20.2 \pm 4.6$ & $15.0 \pm 1.4$ & $81.4 \pm 3.8$ & $68.7 \pm 5.3$ \\
3 & $26.9 \pm 3.3$ & $17.4 \pm 3.7$ & $46.0 \pm 10.5$ & $33.2 \pm 9.9$ \\
4 & $16.4 \pm 3.5$ & $10.4 \pm 1.8$ & $43.8 \pm 8.6$ & $38.7 \pm 3.13$ \\
\hline
\end{tabular}

Values are mean \pm E.E. of the five years evaluated.

Table 6: Degree of correlation (Pearson coefficient) between seasonal growth and climate variables for each site.

\begin{tabular}{|c|c|c|c|c|}
\hline & Site 1 & Site 2 & Site 3 & Site 4 \\
\hline Seasonal precipitation (mm/season) & $0.57^{\star}$ & 0.37 & $0.63^{* *}$ & 0.16 \\
\hline Seasonal ETA (mm/season) & $0.63^{* *}$ & $0.70^{* *}$ & 0.66 * & $0.86^{\star * *}$ \\
\hline Seasonal Incident radiation $\left(\mathrm{MJ} / \mathrm{m}^{2} . \mathrm{d}\right)$ & $0.74^{* *}$ & $0.71^{* * *}$ & $0.47^{*}$ & $0.76^{* * *}$ \\
\hline Seasonal mean temperature $\left({ }^{\circ} \mathrm{C}\right)$ & $0.60 *$ & $0.56^{*}$ & 0.41 & 0.36 \\
\hline
\end{tabular}

ETA: Actual evapotranspiration. Bold denotes significant effects at ${ }^{*} P<0.05 ;{ }^{* *} P<0.001 ;{ }^{* * *} P<0.0001$. 
dent radiation at all the sites (Table 6), and these results agree with those presented in previous studies (Brown et al., 2006; Smeal et al., 1991). This positive relationship between both environmental variables and lucerne growth would be due to the positive association between evapotranspiration rate and radiation with $\mathrm{CO}_{2}$ exchange (Baldocchi, Verma and Rosenberg, 1981). Multiple regressions that consider ETA and incident radiation as independent variables were significant at all the sites. However, the relative weight of incident radiation and ETA were both significant only at Site 2 (Figure 4). At the other sites, although the multiple regressions were significant, the inclusion of ETA and incident radiation did not improve the ability to explain seasonal growth variability, indicating that one of the variables is limiting lucerne growth to a greater extent. In dry environments (Sites 3 and 4), lucerne production is mainly limited by water availability, since precipitation and soil water storage capacity are low. Conversely, Site 1 presented the highest ETA values in months of lucerne active growth (spring and summer) (Table 2). This would be due to the higher temperatures recorded in that period, which also coincides with good water availability owing to high precipitation and soil water retention capacity. Thus, at this site it is incident radiation which limits lucerne growth.

Annual WUE ranged from 9.6 to $18.3 \mathrm{~kg} \mathrm{DM} /$ ha.mm (Figure 5). Previously reported annual WUE values in the literature also vary widely among contrasting environments, finding values between 8.5 to $12 \mathrm{~kg} \mathrm{DM} / \mathrm{ha} . \mathrm{mm}$ in Sudan (Saeed and ElNadi, 1997), 13.83 to $17.70 \mathrm{~kg} \mathrm{DM} / \mathrm{ha} . \mathrm{mm}$ in China (Xu et al., 2006), 12.5 to 24.1 in United States (Rechel et al., 1991; Lindenmayer, Hansen, Brummer and
Pritchett, 2011) and from 9.22 to $16 \mathrm{~kg} \mathrm{DM} / \mathrm{ha} . \mathrm{mm}$ in Australia (Hirth, Haines, Ridley and Wilson, 2001; Pembleton et al., 2011). Physical and chemical soil characteristics may explain this variability, as the lowest annual value corresponded to the site with coarser texture and lower fertility (Site 4) compared to sites with the highest WUE (Sites 1 and 2; Table 1). Additionally, WUE spatial variability may be due to differences in vapor pressure deficit (VPD) among sites (Collino et al., 2005), since increasing the leafto-air water VPD results in stomatal closure (Schulze and Hall, 1982; El-Sharkawy, Cock and Held, 1984). No differences were found in WUE between seasons at Sites 1, 3 and 4 (Figure 6). This similarity in WUE across seasons with large differences in temperature and water availability was previously reported by Hirth et al. (2001). However, WUE was higher in spring than in autumn and winter at Site 2. This variation would be further explained by changes in lucerne growth throughout the year rather than ETA, since the former coefficient variation was much greater than intra-annual ETA variation (71.7 $\%$ vs. $33.9 \%$, respectively). The fact that growth increases more in spring than ETA, would imply that there were other factors that promoted spring growth, that have not been considered in this study. For example, differences in spring growth could be related to increases in mineralization processes as a consequence of higher temperatures, which would have a more significant effect at Site 2, since it presents a more acidic soil than the other sites (Table 1).

The strength of this study lays in the fact it simultaneously analyzes lucerne aboveground biomass observed through several years and at several sites and obtained from trials using the same

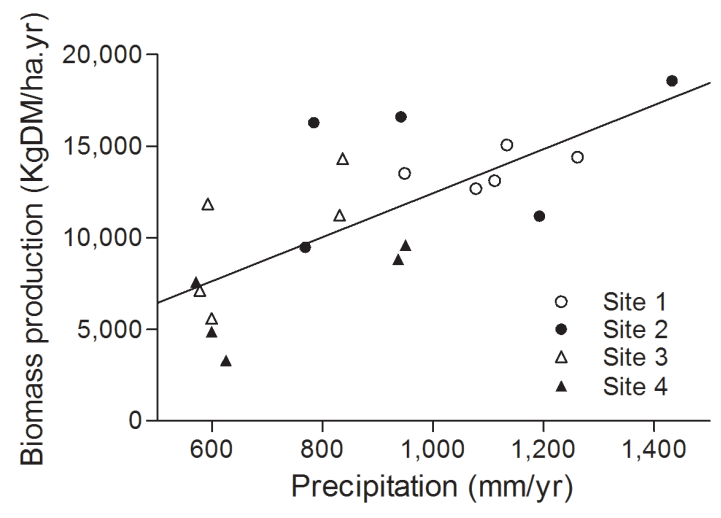

Figure 3: Relationship between lucerne annual biomass production and annual precipitation at four sites in the Pampa region of Argentina: $r=0.71, P<0.001 ; y=996+11.55 x$.

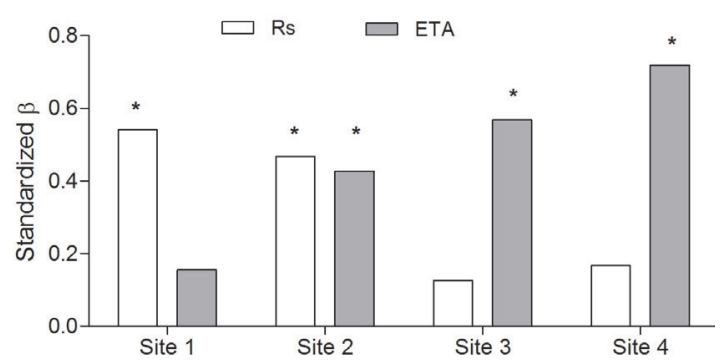

Figure 4:Relative importance (Standardized $\beta$ coefficients) of incident radiation and actual evapotranspiration on seasonal lucerne growth in the multiple regression of each site; * denotes significant $\beta$. Site 1: $y=3.75 \times E T A+5.15 \times R s-7.37(R=0.76)$; Site 2: $y=13.37 \times E T A+5.33 \times R s-23.54(R=0.80)$; Site $3: y=$ $12.10 \times E T A+1.07 \times R s-1.90(R=0.67)$; Site $4: y=11.44 \times$ ETA $+1.97 \times R s-9.65(R=0.87)$. 


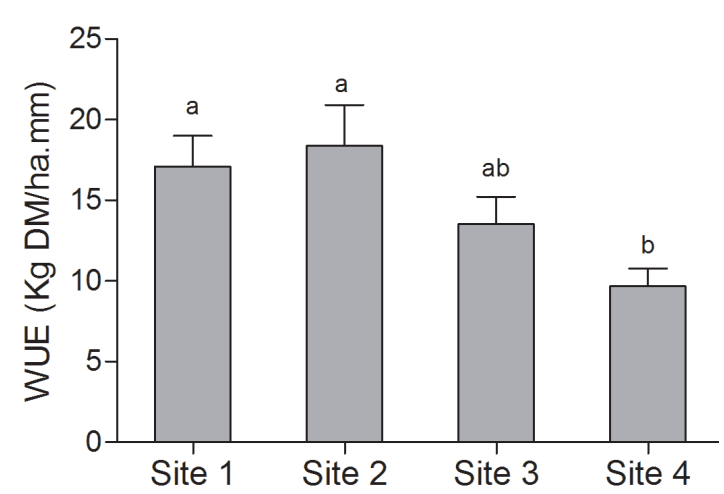

Figure 5: Annual average water use efficiency (WUE) for each site. Values are means \pm SE for five years. Different letters above bars indicate that WUE values significantly differ among sites according to Tukey's test $(P \leq 0.05)$.

protocol. Indeed, these results demonstrate that environmental controls of lucerne growth vary between spatial and temporal scale. At spatial scale, growth variability was explained by annual precipitation and by differences in WUE among sites. At temporal scale, the interannual growth variation was explained by precipitation of the growing season in drier sites, with less water retention capacity soils. Seasonal growth variations were explained by seasonal incident radiation and seasonal actual evapotranspiration in all sites. However, the variation explained by each of these variables depended on the site. This information is a fundamental piece of knowledge to a better understanding of the ecophysiology and adaptation of lucerne for forage production. Part of the spatial and temporal variation in lucerne growth not explained by climatic variables could be attributed to the genetic differences between plants of the same cultivar, seed origin and plant density achieved in each site and year (Julier, Huyghe and Ecalle, 2000; Dolling, Lyons and Latta, 2011). Knowing the sources of lucerne growth variability, would allow developing more efficient livestock management due to less uncertainty on the dynamics of forage production (Campbell and Stafford Smith, 2000).

\section{ACKNOWLEDGEMENTS}

This research was supported by grants from Universidad de Buenos Aires and Agencia Nacional de Investigaciones Científicas y Técnicas (Argentina). The authors gratefully acknowledge Maria Dubois, Maria del Carmen Spada and managers of experimental stations that integrate the Chamber of Seed Traders and INTA networks. The construc-

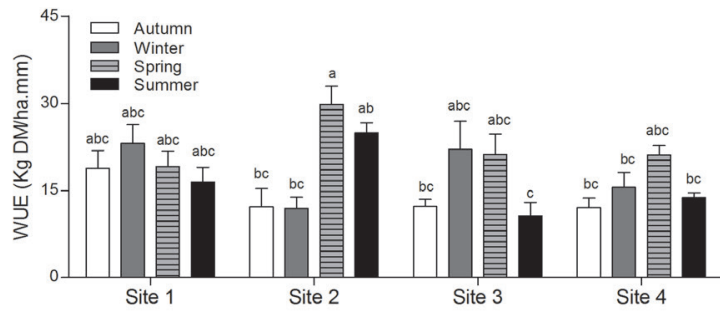

Figure 6: Seasonal water use efficiency (WUE) for each site. Values are means \pm SE for five years. The same letter above bars indicates that values do not significantly differ among sites or seasons $(P<0.05)$. Different letters above bars indicate WUE values significantly differ among seasons and / or sites, according to Tukey's test $(P \leq 0.05)$.

tive comments of two anonymous reviewers have greatly enhanced the quality of the paper.

\section{REFERENCES}

Allen, R.G., Pereira, L.S., Raes, D. and Smith, M. (1998). Crop evapotranspiration - Guidelines for computing crop water requirements. Irrigation and Drainage Papers (Food and Agriculture Organization), 56.

Baldocchi, D. D., Verma, S.B. and Rosenberg, N. J. (1981). Environmental effects on the $\mathrm{CO}_{2}$ flux and $\mathrm{CO}_{2}$-Water flux ratio of Alfalfa. Agricultural Meteorology, 24(0), 175-184.

Basigalup, D. H. and Ustarroz, E. (2007). Grazing alfalfa systems in the Argentinean Pampas, Proceedings of the 37th California Alfalfa and Forage Symposium -Alfalfa: Back to the Basics, Monterey, California, pp. 53-62.

Bissio, J. C. (1996). Curva de producción del pastizal de cola de zorro, pasto horqueta y pasto macho. Publicación para Extensión. Área de Investigación en Producción Ganadera, Reconquista, Santa Fe, pp. 6.

Boix-Fayos, C., Calvo-Cases, A., Imeson, A. C., Soriano-Soto, M. D. and Tiemessen, I. R. (1998). Spatial and short-term temporal variations in runoff, soil aggregation and other soil properties along a mediterranean climatological gradient. CATENA, 33(2), 123-138.

Bowman, A. M., Smith, W. and Brockwell, J. (2004). Forecasting lucerne productivity under dryland farming conditions in central-western and western New South Wales. Soil Biology and Biochemistry, 36(8), 12531260.

Brown, H. E., Moot, D. J. and Teixeira, E. I.(2006). Radiation use efficiency and biomass partitioning of lucerne (Medicago sativa) in a temperate climate. European Journal of Agronomy, 25(4), 319-327.

Campbell, B. D. and Stafford Smith, D. M. (2000). A synthesis of recent global change research on pasture 
and rangeland production: reduced uncertainties and their management implications. Agriculture, Ecosystems \& Environment, 82, 39-55.

Campiglia, E., Caporali, F., Barberi, R. and Mancinelli, R. (1999). Influence of 2-, 3-, 4- and 5 -year stands of alfalfa on winter wheat yield. In: Olesen, J. E., Eltun, R., Goodlimg, M. J.,Jensen, E. S. and Köpke, U. (Editors), Designing and Testing Crop Rotations for Organic Farming. Tjele, Denmark:Danish research in organic food and farming.

Collino, D. J., Dardanelli, J. L., De Luca, M. J. and Racca, R.W. (2005). Temperature and water availability effects on radiation and water use efficiencies in alfalfa (Medicago sativa L.). Australian Journal of Experimental Agriculture, 45(4), 383-390.

Di Bella, C. M., Negri, I. J., Posse, G., Jaimes, F. R., Jobbagy, E. G., Garbulsky, M. F. and Deregibus, V. (2009). Forage Production of the Argentine Pampa Region Based on Land Use and Long-Term Normalized Difference Vegetation Index Data. Rangel and Ecology \& Management, 62(2), 163-170.

Di Rienzo, J. A., Casanoves, F., Balzarini, M. G., Gonzalez, L., Tablada, M. y Robledo, C. W. (2011).InfoStat. Grupo InfoStat, FCA, Universidad Nacional de Córdoba, Argentina.

Dolling, P. J., Lyons, A. M. and Latta, R. A. (2011). Optimal plant densities of lucerne (Medicago sativa) for pasture production and soil water extraction in mixed pastures in south-western Australia. Plant and Soil, 348(1), 315-327.

Dovrat, A. (1993). Irrigated Forage Production.New York, United States: Elsevier.

Droogers, P. and Allen, R.G. (2002). Estimating Reference Evapotranspiration Under Inaccurate Data Conditions. Irrigation and Drainage Systems, 16(1), 33-45.

El-Sharkawy, M.A., Cock, J.H. and Held, K.A.A. (1984). Water use efficiency of cassava. II. Differing sensitivity of stomata to air humidity in cassava and other warmclimate species. Crop Science, 24, 503-507.

Fabricante, I., Oesterheld, M. and Paruelo, J. M. (2009). Annual and seasonal variation of NDVI explained by current and previous precipitation across Northern $\mathrm{Pa}-$ tagonia. Journal of Arid Environments, 73(8), 745-753.

Fay, P., Carlisle, J., Knapp, A., Blair, J. and Collins, S. (2003). Productivity responses to altered rainfall patterns in a C4-dominated grassland. Oecologia, 137(2), 245-251.

Fetcher, N. and Trlica, M. J. (1980). Influence of Climate on Annual Production of Seven Cold Desert Forage Species. Journal of Range Management, 33(1), 35-37.

Garbulsky, M. F., Peñuelas, J., Papale, D., Ardö, J., Goulden, M. I., Kiely, G. ... and Fillela, I. (2010). Patterns and controls of the variability of radiation use efficien- cy and primary productivity across terrestrial ecosystems. Global Ecology and Biogeography, 19(2), 253267.

Gattinger, A., Muller, A., Haeni, M., Skinner, C., Fliessbach, A, Buchmann, N., ... and Niggli, U. (2012). Enhanced top soil carbon stocks under organic farming. Proceedings of the National Academy of Sciences, 109(44), 18226-18231.

Hakl, J., Fuksa, P., Konecná, J., Pacek, L. and Tlustoš, P. (2014). Effect of applied cultivation technology and environmental conditions on lucerne farm yield in the Central Europe.Plant, Soil and Environment, 60(10), 475-480.

Hargreaves, G. H. (1994). Simplified coefficients for estimating monthly solar radiation in North America and Europe.Logan, EstadosUnidos: Utah State University.

Hargreaves, G. H. and Samani, Z. A. (1985).Reference crop evapotranspiration from temperature.AppliedEngineering in Agriculture 1, 96-99.

Hirth, J.R., Haines, P.J., Ridley, A.M. and Wilson, K.F. (2001).Lucerne in crop rotations on the Riverine Plains. 2. Biomass and grain yields, water use efficiency, soil nitrogen, and profitability. Australian Journal of Agricultural Research, 52(2), 279-293.

Huyghe, C. (2003). Les fourrageset la production de protéines. Acte des Journées de l'Association France, aise pour la Production Fourragère (AFPF). Paris: AFPF.

Jackson, R. B., Schenk, H. J., Jobbagy, E. G., Canadell, J., Colello, G. D., Dickinson, R. E. ... and Sykes, M. T. (2000). Belowground consequences of vegetation change and their treatment in models. Ecological Applications, 10(2), 470-483.

Jarvis, S. C., Stockdale, E. A., Shepherd, M. A. and Powlson, D. S.(1996). Nitrogen mineralization in temperate agriculture soils: processes and management. Advances in Agronomy, 57, 187-235.

Julier, B., Huyghe, C. and Ecalle, C. (2000). Within- and Among-Cultivar Genetic Variation in Alfalfa: Forage Quality, Morphology, and Yield. Crop Science, 40(2), 365-369.

Knapp, A. K. and Smith, M. D.(2001). Variation Among Biomes in Temporal Dynamics of Aboveground Primary Production. Science, 291(5503), 481-484.

Lindenmayer, R. B., Hansen, N. C., Brummer, J. and Pritchett, J. G. (2011). Deficit Irrigation of Alfalfa for Water-Savings in the Great Plains and Intermountain West: A Review and Analysis of the Literature.Agronomy Journal, 103(1), 45-50.

Lo Seen Chong, D., Mougin, E. and Gastellu-Etchegorry, J. P. (1993). Relating the Global Vegetation Index to net primary productivity and actual evapotranspiration over Africa. International Journal of Remote Sensing, 14(8), 1517-1546. 
Ma, B. L., Liang, B. C., Biswas, D. K., Morrison, M. J. and McLaughlin, N. B.(2012). The carbon footprint of maize production as affected by nitrogen fertilizer and maize-legume rotations. NutrientCycling in Agroecosystems, 94(1), 15-31.

Mattera, J., Romero, L. A., Cuatrín, A. L., Cornaglia, P. S. and Grimoldi, A. A. (2013). Yield components, light interception and radiation use efficiency of lucerne (Medicago sativa L.) in response to row spacing. European Journal of Agronomy, 45(0), 87-95.

McKenzie, N. J. and Ryan, P. J. (1999).Spatial prediction of soil properties using environmental correlation. Geoderma, 89, 67-94.

McNaughton, S. J., Oesterheld, M., Frank, D. A. and Williams, K. J. (1989). Ecosystem-level patterns of primary productivity and herbivory in terrestrial habitats. Nature, 341, 142-144.

Moscatelli, G. and Puentes, M. I. (1998). Suelos argentinos. In: Conti, M. (Editor), Principios de Edafología, con énfasis en suelos argentinos. Buenos Aires, Argentina: Orientación Gráfica Editora.

Murphy, A. H. (1970). Predicted Forage YieldBasedon Fall Precipitation in California Annual Grasslands. Journal of Range Management, 23(5), 363-365.

Pasturat Test. (1991). Resultados de la campaña 1990/1991. Red de ensayos de variedades forrajeras. Cámara de Semilleristas de la Bolsa de Cereales (Eds.). Buenos Aires, Argentina.

Pasturat Test. (1995). Resultados de la campaña 1994/1995. Red de ensayos de variedades forrajeras. Cámara de Semilleristas de la Bolsa de Cereales (Eds.). Buenos Aires, Argentina.

Pasturat Test. (1997). Resultados de la campaña 1996/1997. Red de ensayos de variedades forrajeras. Cámara de Semilleristas de la Bolsa de Cereales (Eds.). Buenos Aires, Argentina.

Pasturat Test. (1998). Resultados de la campaña 1997/1998. Red de ensayos de variedades forrajeras. Cámara de Semilleristas de la Bolsa de Cereales (Eds.). Buenos Aires, Argentina.

Pasturat Test. (1999). Resultados de la campaña 1998/1999. Red de ensayos de variedades forrajeras. Cámara de Semilleristas de la Bolsa de Cereales (Eds.). Buenos Aires, Argentina.

Pasturat Test. (2000). Resultados de la campaña 1999/2000. Red de ensayos de variedades forrajeras. Cámara de Semilleristas de la Bolsa de Cereales (Eds.). Buenos Aires, Argentina.

Pasturat Test. (2001). Resultados de la campaña 2000/2001. Red de ensayos de variedades forrajeras. Cámara de Semilleristas de la Bolsa de Cereales (Eds.). Buenos Aires, Argentina.

Pasturat Test. (2003). Resultados de la campaña
2002/2003. Red de ensayos de variedades forrajeras. Cámara de Semilleristas de la Bolsa de Cereales (Eds.). Buenos Aires, Argentina.

Pasturat Test. (2004). Resultados de la campaña 2003/2004 Red de ensayos de variedades forrajeras. Cámara de Semilleristas de la Bolsa de Cereales (Eds.). Buenos Aires, Argentina.

Pasturat Test. (2005). Resultados de la campaña 2004/2005. Red de ensayos de variedades forrajeras. Cámara de Semilleristas de la Bolsa de Cereales (Eds.). Buenos Aires, Argentina.

Pembleton, K.G., Rawnsley, R.P. and Donaghy, D.J.(2011). Yield and water-use efficiency of contrasting lucerne genotypes grown in a cool temperate environment. Cropand Pasture Science, 62(7), 610-623.

Primavesi, A. (1999). Manejo ecológico de pastagens: em regiões tropicais e subtropicais. Sao Paulo, Brasil: Nobel.

Raich, J. and Tufekciogul, A. (2000). Vegetation and soil respiration: Correlations and controls. Biogeochemistry, 48(1),71-90.

Rechel, E. A., De Tar, W. R., Meek, B. D. and Carter, L. M.(1991). Alfalfa (Medicago sativa L.) water use efficiency as affected by harvest traffic and soil compaction in a sandy loam soil. Irrigation Science, 12(2), 61-65.

Ritchie, J. (1981). Water dynamics in the soil-plant-atmosphere system. Plant and Soil, 58(1-3), 81-96.

Robinson, T., La Pierre, K. J., Vadeboncoeur, M. A., Byrne, K. M., Thomey, M. L. and Colby S. E. (2012). Seasonal, not annual precipitation drives community productivity across ecosystems. Oikos, 122(5), 727-738.

Sadras, V. O. and Milroy, S. P. (1996). Soil-water thresholds for the responses of leaf expansion and gas exchange: A review. Field Crops Research, 47, 253-266.

Sadras, V. O., Villalobos, F. J. and Fereres, E. (1993). Leaf Expansion in Field-Grown Sunflower in Response to Soil and Leaf Water Status. Agronomy Journal, 85(3),564-570.

Saeed, I. A. M. and El-Nadi, A. H.(1997). Irrigation effects on the growth, yield, and water use efficiency of alfalfa. Irrigation Science, 17(2),63-68.

Sala, O. E., Gherardi, L. A., Reichmann, L., Jobbágy, E. and Peters, D. (2012). Legacies of precipitation fluctuations on primary production: theory and data synthesis. Philosophical Transactions of the Royal Society B: Biological Sciences, 367(1606), 3135-3144.

Samani, Z. (2000). Estimating Solar Radiation and Evapotranspiration Using Minimum Climatological Data. Journal of Irrigation and Drainage Engineering, 126(4), 265-267.

Saxton, K.E., Raels, W.J., Romberger, J. and Papendick, R. (1986). Estimating generalized soil-water charac- 
teristics from texture. Soil Science Society of America Journal, 50(4), 1031-1036.

Schulze, E.D. and Hall, A.E. (1982).Stomatal responses, water loss and $\mathrm{CO}_{2}$ assimilation rates of plants in contrasting environments. In: Lange, O.L., Nobel, P.S., Osmond, C.B. and Zeiger, H. (Editors), Physiological Plant Ecology II: Water Relations and Carbon Assimilation. Berlin, Germany: Springer.

Singh, J. B., Behari, P. and Yadava, R. B.(2007). On the estimation of evapotranspiration, water-use efficiency and crop coefficient of lucerne (Medicago sativa L.) in central India.Current Science 93(1), 17-19.

Smeal, D., Gregory, E. J. and Arnold, R. N.(1992).Interseasonal Variability in the Water Use-Production function of Alfalfa. Journal of Production Agriculture, 5(4), 576-580.

Smeal, D., Kallsen, C. E. and Sammis, T. W.(1991). Alfalfa yield as related to transpiration, growth stage and environment. Irrigation Science, 12(2), 79-86.

Spada, M. d. C., Olivo, S. M., Mattera, J., Ugarte, C. C.,
García, J. M., Bolletta, A. I., Re, A. E., Di Nucci, E., Fontana, L. M. C., Funes, M. O., Gallego J. J., Neira Zilli, F., Mijoevich, M. L., Frigerio, K. L., Amigone, M. A., Romero, L. A., Cornacchione, M., Crosetti, D. A. (2015). Directorio de Avances en Alfalfa. Retrieved from https://inta.gob.ar/documentos/directoriode-avances-en-alfalfa.

Teague, W. R., Apfelbaum, S., Lal, R., Kreuter, U. P., Rowntree, J., Davies, C. A., Conser, R., Rasmussen, M., Hatfield, J., Wang, T., Wang, F., Byck, P. (2016). The role of ruminants in reducing agriculture's carbon footprint in North America. Journal of Soil and Water Conservation, 71(2), 156-164.

Xu, B. C., Gichuki, P., Shan, L. and Li, F. M. (2006). Aboveground biomass production and soil water dynamics of four leguminous forages in semiarid region, northwest China. South African Journal of Botany, 72(4), 507-516.

Xu, C.Y. and Singh, V. P. (2001). Evaluation and generalization of temperature-based methods for calculating evaporation. Hydrological Processes, 15(2), 305-319. 